\title{
Replication and persistence of VHSV IVb in freshwater turtles
}

\author{
Andrew E. Goodwin*, Gwenn E. Merry \\ University of Arkansas at Pine Bluff Aquaculture/Fisheries Center, 1200 N. University Dr., Pine Bluff, Arkansas 71601, USA
}

\begin{abstract}
With the emergence of viral hemorrhagic septicemia virus (VHSV) strain IVb in the Great Lakes of North America, hatchery managers have become concerned that this important pathogen could be transmitted by animals other than fish. Turtles are likely candidates because they are poikilotherms that feed on dead fish, but there are very few reports of rhabdovirus infections in reptiles and no reports of the fish rhabdoviruses in animals other than teleosts. We injected common snapping turtles Chelydra serpentine and red-eared sliders Trachemys scripta elegans intraperitoneally with $10^{4}$ median tissue culture infectious dose (TCID ${ }_{50}$ ) of VHSV-IVb and $21 \mathrm{~d}$ later were able to detect the virus by quantitative real-time reverse transcriptase PCR (qrt-RTPCR) in pools of kidney, liver, and spleen. In a second experiment, snapping turtles, red-eared sliders, yellow-bellied sliders T. scripta scripta, and northern map turtles Grapetemys geographica at $14^{\circ} \mathrm{C}$ were allowed to feed on tissues from bluegill dying of VHSV IVb disease. Turtle kidney, spleen, and brain pools were not positive by qrt-RTPCR on Day 3 post feeding, but were positive on Days 10 and 20. Map turtles on Day 20 post-feeding were positive by both qrt-RTPCR and by cell culture. Our work shows that turtles that consume infected fish are a possible vector for VHSV IVb, and that the fish rhabdoviruses may have a broader host range than previously suspected.
\end{abstract}

KEY WORDS: VHS · Vector $\cdot$ Carrier $\cdot$ Turtles $\cdot$ PCR

Resale or republication not permitted without written consent of the publisher

\section{INTRODUCTION}

The viral hemorrhagic septicemia virus (VHSV) strain IVb was first detected in the Great Lakes of North America in 2003 (Elsayed et al. 2006). It has since been found in all of the Great Lakes, Lake St. Clair, in the St. Lawrence River, and in several inland lakes including one outside the Great Lakes watershed (reviewed by Bain et al. 2010). The virus has been detected in many species of fish in 13 different families and has produced large fish kills in freshwater drum Aplodinotus grunniens, muskellunge Esox masquinongy, gizzard shad Dorosoma cepedianum, and round gobies Neogobius melanostomus. It has been detected in important sport and aquaculture species including smallmouth bass Micropterus dolomieui, yellow perch Perca flavescens, channel catfish Ictalurus puntatus, bluegill Lepomis macrochirus, and coho salmon Oncorhynchus kisutch (Batts \& Winton 2007, Lumsden et al. 2007).

All of the detections of VHSV IVb thus far have been in wild fish in natural systems, but there is a great deal of concern about the likely result of introducing the virus into state and federal fish hatcheries or commercial aquaculture. These concerns are related both to the potential for significant mortality of susceptible species held at high density and to the likely regulatory impact of the discovery of VHSV IVb in a private or public aquaculture facility. Based on precedents set during the first discoveries of spring viremia of carp virus (SVCV) in the United States (Goodwin 2002, Miller et al. 2007), the detection of VHSV IVb on a hatchery is likely to result in quarantine and perhaps efforts to eradicate infected fish populations and disinfect the facility.

To reduce the likelihood of introducing VHSV IVb into cultured fish populations, farmers and hatchery 
managers have increased the efforts to design and implement biosecurity programs. The main focus of such programs is to prevent introductions of the virus via infected fish, unprotected water sources, or contaminated equipment, but there is also concern that animal vectors might bypass current farm biosecurity measures and introduce the virus.

The most likely animal vectors are aquatic animals that prey on sick fish and that move easily onto farms or between ponds. Fish-eating birds are a candidate for concern, but their gastric fluids are likely to inactivate the virus (Peters \& Neukirch 1986), and their body temperatures are far above the limit for VHSV IVb replication in vitro (Hawley \& Garver 2008). Thus, VHSV IVb is unlikely to survive transit through a bird, nor will it be able to establish a low level infection in a bird host. Poikilotherms, especially aquatic turtles and snakes that prey on fish, are more likely to be vectors, but little is known about the susceptibility of reptiles to fish rhabdoviruses. In the present study, we challenged common turtle species with VHSV by both intraperitoneal (i.p.) injection and by an oral route and looked for evidence that reptiles may serve as a vector for VHSV IVb.

\section{MATERIALS AND METHODS}

Preparation and titer of VHSV IVb stocks. The Great Lakes strain of VHSV IVb, originally isolated from freshwater drum in the Bay of Quinte, Lake Ontario, Canada (Lumsden et al. 2007) was propagated in $150 \mathrm{~cm}^{2}$ flasks containing fathead minnow (FHM) cells in L-15 medium with $10 \%$ fetal bovine serum at $15^{\circ} \mathrm{C}$. Aliquots $(2 \mathrm{ml})$ of supernatant were frozen at $-80^{\circ} \mathrm{C}$ and later serially diluted on FHM cells. The mean median tissue culture infective dose ( TCID $_{50}$ ) was $1 \times 10^{7.2} \mathrm{PFU} \mathrm{ml} \mathrm{m}^{-1}$. By quantitative real time reverse transcriptase (qrt-RTPCR) the concentration of the virus was $1 \times 10^{7.4}$ copies $\mathrm{ml}^{-1}$.

Expt 1: i.p. challenge with VHSV. Three 4.51 plastic containers were filled with $500 \mathrm{ml}$ dechlorinated tap water $\left(\mathrm{pH}\right.$ 6.75, alkalinity $40 \mathrm{mg} \mathrm{l}^{-1}$, hardness $170 \mathrm{mg} \mathrm{l}^{-1}$, chloride $400 \mathrm{mg} \mathrm{l}^{-1}$ ) and floated in a water bath at $14^{\circ} \mathrm{C}$. The containers were stocked with turtles obtained from a commercial farm in Arkansas, USA. Containers 1, 2, and 3 were stocked with two $12 \mathrm{~cm}$ red-eared sliders Trachemys scripta elegans, seven 6 to $8 \mathrm{~cm}$ red-eared sliders, and seven 6 to $8 \mathrm{~cm}$ common snapping turtles Chelydra serpentine, respectively. Ammonia, pH, nitrite, alkalinity, hardness, and chlorides were measured in each container prior to the study. The turtles were acclimated for $21 \mathrm{~d}$ prior to the challenge and fed a floating trout diet during the study.
After acclimation, turtles were challenged with $100 \mu$ i.p. injection of previously frozen VHSV IVb diluted 1:10 with HBSS (Hank's Balanced Salt Solution; Sigma) for a final dose of $10^{4} \mathrm{TCID}_{50}$ per turtle. Intraperitoneal injections were administered posterior to the rear leg along the margin of the femoral scute. Water samples $(1 \mathrm{ml})$ were taken daily in each container and immediately frozen at $-80^{\circ} \mathrm{C}$ for later nucleic acid extraction and qrt-RTPCR determination.

On Day 21 post injection, turtles were euthanized according to AVMA (2007) guidelines and individual kidney, spleen, and lung samples were pooled and weighed (approximately $25 \mathrm{mg}$ ) into $2.0 \mathrm{ml}$ tubes. One $\mathrm{ml}$ of HBSS and a $5 \mathrm{~mm}$ stainless steel bead were added to each tube and homogenized for $1 \mathrm{~min}$ at $13 \mathrm{~Hz}$ in a TissueLyzer bead mill (Qiagen). Tubes were centrifuged at $20000 \times g$ at $4^{\circ} \mathrm{C}$ for $5 \mathrm{~min}$. Triplicate tenfold serial dilutions were made beginning with $5 \mu \mathrm{l}$ of each supernatant on 384 well plates containing FHM monolayers. Remaining supernatant was immediately frozen at $-80^{\circ} \mathrm{C}$ for later nucleic acid extraction and qrt-RTPCR determination.

qrt-RTPCR for VHSV IVb. Total RNA was extracted from $100 \mu \mathrm{l}$ of cell supernatant and eluted in $40 \mu \mathrm{l}$ water using a commercial kit (RNeasy Kit; Qiagen). Total RNA from turtle tissues was extracted using an RNeasy Kit and TissueLyzer (Qiagen) according to manufacturer's recommendations, with an elution volume of $40 \mu \mathrm{l}$. The RNA and DNA from water samples were co-extracted from thawed water using a VX Kit (Qiagen), TissueLyzer, and QiAxtractor (Qiagen) according to manufacturer's recommendations, with a sample volume of $200 \mu \mathrm{l}$ and an elution volume of $75 \mu \mathrm{l}$. Extracted nucleic acid was aliquoted and frozen at $-80^{\circ} \mathrm{C}$ for qrt-RTPCR. Total nucleic acid concentration was measured spectrophotometrically (Nanodrop ND-1000; Nanodrop).

The 1-step qrt-RTPCR was done according to Hope et al. (2010) using a BioRad iCycler iQ (BioRad). Duplicate $25 \mu \mathrm{l}$ reactions included 12.5 $\mathrm{ll}$ QuantiTect Probe RTPCR Master Mix (Qiagen), $0.5 \mu$ of $10 \mu \mathrm{M}$ forward primer (200 nM final conc.), $0.5 \mu$ l of $10 \mu \mathrm{M}$ reverse primer (200 nM final conc.), $0.5 \mu \mathrm{l}$ of $10 \mu \mathrm{M}$ FAM-labeled probe (200 nM final conc.), $0.75 \mu \mathrm{l}$ water, and $0.25 \mu \mathrm{l}$ QuantiTect RT Mix (Qiagen). Sample template was loaded at $10 \mu \mathrm{l}(<300 \mathrm{ng})$ per reaction. A plasmid containing the amplified target was made using the Invitrogen TOPO-TA cloning kit (Invitrogen). This was purified using a QiAprep spin Miniprep Kit (Qiagen), and a dilution series was used to create a standard curve for quantitative analysis. Absolute copy number in unknown samples was determined from a standard regression fit using the supplier's software. A sample of total RNA from a VHSV-infected cell culture was run in duplicate and served as an RT control. A no-template control con- 
taining $10 \mu$ of water was run in duplicate for each assay. Positive and negative extraction controls were included in duplicate on every run.

Expt 2: Oral challenge by VHSV-infected bluegill Lepomis macrochirus tissues. Three independent 1501 recirculating aquarium systems were stocked with turtle hatchlings which still had internal yolk reserves: one with 27 common snapping turtles Chelydra serpentina, one with a total of 84 yellow-bellied Trachemys scripta scripta and red-eared Trachemys scripta elegans sliders, and the last with 39 northern map turtles Grapetemys geographica. Turtles were acclimated at $21^{\circ} \mathrm{C}$ for $3 \mathrm{wk}$, then the temperature was dropped to $14^{\circ} \mathrm{C}$ over a $4 \mathrm{~d}$ period beginning $8 \mathrm{~d}$ before the VHSV challenge was begun.

Infected bluegill tissues were produced by obtaining 30 bluegill $(7$ to $8 \mathrm{~cm}$ ) from a commercial source and acclimating them at $21^{\circ} \mathrm{C}$ for $3 \mathrm{wk}$ in $300 \mathrm{l}$ recirculating aquarium systems with biofilters and heat pumps. Water temperatures were lowered to $11^{\circ} \mathrm{C}$ over a $3 \mathrm{~d}$ period. The bluegill were injected with $10^{4} \mathrm{TCID}_{50}$ VHSV Type IVb using the same frozen aliquots as in Expt 1 and held at $11^{\circ} \mathrm{C}$.

The bluegill injected with VHSV began to show clinical signs of VHSV disease at $3 \mathrm{~d}$ post injection. On Day 4, and over the following $5 \mathrm{~d}, 6$ to 11 moribund bluegill were euthanized according to AVMA (2007) guidelines, cut into 2 to $5 \mathrm{~mm}$ pieces and offered to the turtles in all 3 aquarium systems. A daily subsample of chopped moribund bluegill was titered on epithelioma papillosum cyprini cells. Following 5 d of feeding with infected bluegill tissues, the turtles were fed commercial trout ration daily for 20 d. On Days 3, 10, and 20, turtles were euthanized, and approximately $80 \mathrm{mg}$ of individually pooled brain, kidney, and spleen samples were processed for qrt-RTPCR and cell culture (see Table 1) as described in Expt 1. Tissues were also collected from turtles that died during the experiment. These tissues were preserved in RNAlater (Qiagen) and stored at $-80^{\circ} \mathrm{C}$ for later nucleic acid extraction and qrt-RTPCR.

\section{RESULTS}

\section{Expt 1: i.p. challenge with VHSV IVb}

No mortality occurred during the i.p. challenge experiment. The plasmid standard produced a linear dose response over 8 orders of magnitude $\left(7.67 \times 10^{7}\right.$ to $7.67 \times 10^{\circ}$ ), with consistent detection down to 7.67 copies per reaction. The PCR efficiency was $97.2 \pm 7.1$ over 3 runs. By qrt-RTPCR, $89 \%$ of red-eared sliders and $86 \%$ of common snapping turtles were positive for VHSV on Day 21. Two of the red-eared sliders were
Table 1. Detection of viral hemorrhagic septicemia virus (VHSV) strain IVb in turtles (common snapping turtles Chelydra serpentine, red-eared sliders Trachemys scripta elegans, yellow-bellied sliders $T$. s. scripta, and northern map turtles Grapetemys geographica) exposed to the virus by an oral route. Prevalence and mean copies $( \pm$ SD) of VHSV per mg host tissue were determined by quantitative real time reverse transcriptase PCR (qrt-RTPCR). Cell culture status was determined by inoculation of FHM cells. -: no data

\begin{tabular}{|lccc|}
\hline Time point & Prevalence & $\begin{array}{c}\text { Mean copies } \\
\mathrm{mg}^{-1}\end{array}$ & $\begin{array}{c}\text { Cell culture } \\
\text { status }\end{array}$ \\
\hline Northern map & & & \\
Day 3 & 0 of 10 & 0 & Negative \\
Day 10 & 6 of 7 & $525 \pm 683$ & $\begin{array}{c}\text { Negative } \\
\text { Doy 20 }\end{array}$ \\
2 of 15 & $1180 \pm 1570$ & Positive \\
Sliders & & & \\
Day 3 & 0 of 10 & 0 & Negative \\
Day 10 & - & - & - \\
Day 20 & - & - & - \\
Common snapping & & \\
Day 3 & 0 of 10 & 0 & Negative \\
Day 10 & 2 of 15 & $12 \pm 17$ & Negative \\
Day 20 & - & - & - \\
\hline
\end{tabular}

positive but below 7.67 copies per reaction. Mean copy number of VHSV IVb g ${ }^{-1}$ host tissue was $1.07 \times 10^{3} \pm$ $2.21 \times 10^{3}$ for positive red-eared slider tissue pools and $6.46 \times 10^{4} \pm 4.91 \times 10^{3}$ for positive common snapping turtle pools. No VHSV was detected by cell culture. Water tested by qrt-RTPCR for VHSV IVb was positive in each container during the experiment (Fig. 1). The quality of the RNA extracted from water, expressed as UV absorbance wavelength ratios (260/280 and 260/ $230)$, was $1.59 \pm 0.33$ and $0.09 \pm 0.05$, respectively, and for turtle tissue $1.77 \pm 0.34$ and $0.70 \pm 0.73$.

\section{Expt 2: Oral challenge by VHSV-infected bluegill tissues}

Chopped bluegill tissues fed to the turtles had a mean $( \pm \mathrm{SD})$ VHSV titer of $1 \times 10^{6.5} \pm 1 \times 10^{1.4} \mathrm{TCID}_{50} \mathrm{~g}^{-1}$. Mean turtle tissue weight was $(81 \pm 27 \mathrm{mg})$. Turtle tissue RNA quality expressed as UV absorbance wave-length ratios $(260 / 280$ and $260 / 230)$ was $1.84 \pm 0.19$ and $0.53 \pm 0.29$, respectively. The plasmid standard produced a linear dose response over 8 orders of magnitude $\left(7.67 \times 10^{7}\right.$ to $7.67 \times 10^{0}$ ), with consistent detection down to 7.67 copies per reaction. PCR efficiency was $90.6 \pm 2.9 \%$ over 5 runs. The northern map turtles appeared to consume more bluegill tissue than did the sliders. Common snapping turtles appeared to eat the least. The sliders were removed from the study prior to the Day 10 sample because of a mechanical malfunction that increased water temperatures to over $21^{\circ} \mathrm{C}$ in that aquarium. 


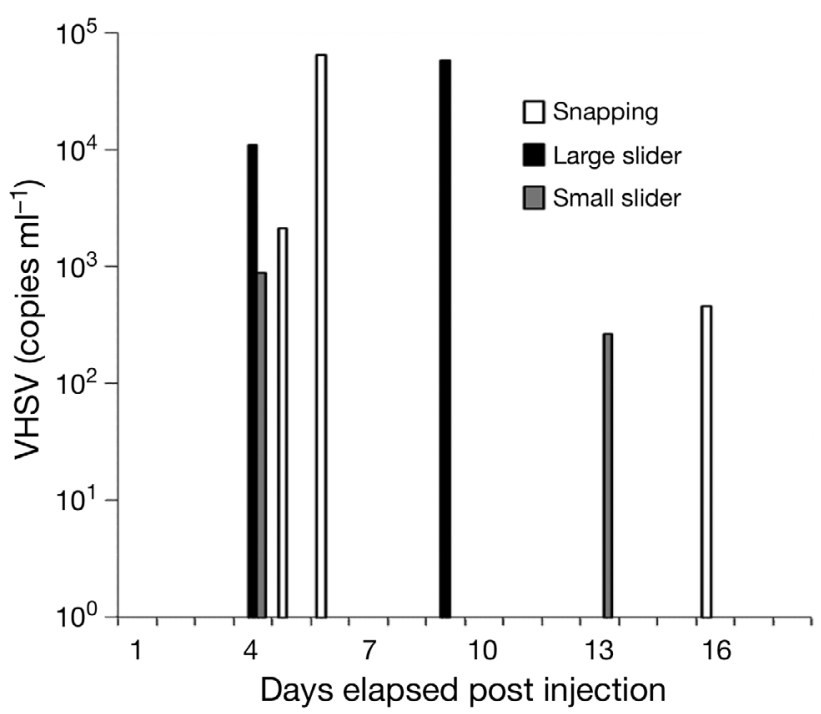

Fig. 1. Detection of viral hemorrhagic septicemia virus (VHSV) strain IVb by quantitative real-time reverse transcriptase PCR (qrt-RTPCR) in water from containers holding turtles (common snapping turtles Chelydra serpentine and red-eared sliders Trachemys scripta elegans), injected intraperitoneally with the virus. Data is expressed as copies of the VHSV IVb genome $\mathrm{ml}^{-1}$

Mortality during the experiment totaled 2 of 27 snapping turtles, 10 of 84 sliders, and 12 of 39 northern map turtles. There was an epizootic of a bacterial lung disease that killed 7 map turtles between Days 11 and 19. Only 2 of these 7 turtles were positive for VHSV IVb by qrt-RTPCR, and they had copy numbers of 380 and 680 copies $\mathrm{g}^{-1}$ host tissue.

None of the 10 turtles of each species that were tested at $3 \mathrm{~d}$ after the cessation of bluegill feeding was positive for VHSV by qrt-RTPCR. At $10 \mathrm{~d}, 6$ of 7 map turtles and 2 of 15 snapping turtles were VHSV-positive. At 20 d, 2 of 15 map turtles were VHSV positive by qrt-RTPCR. Only the 2 positive map turtles sampled on Day 20 were positive for VHSV by cell culture (Table 1), which was further confirmed by qrt-RTPCR and sequencing (Genewiz). The virus titer was between 2000 to 20000 copies $^{-1}$ tissue.

\section{DISCUSSION}

There are very few reports of rhabdovirus infections in reptiles. The Charleville rhabdovirus was isolated from the house gecko Gehyra australis in Australia (Doherty et al. 1973), and the Marco virus and members of the Timbo group were isolated from the green garden lizard Ameiva ameiva in Brazil (Monath et al. 1979). The Charleville virus is of the Emphemerovirus genus in the family Rhabdoviridae and the Marco virus and Timbo group have not been assigned to a genus.
The Ephemeroviruses are typically found in mammals and insects. The VHS virus is in the Novirhabdovirus genus, and all of the fish rhabdoviruses are found in this genus or in the Vesiculovirus genus (Hogenhouet et al. 2003, Van Regenmortel et al. 2005). No virus species in the Novirhabdovirus or Vesiculovirus genera has ever been reported in a reptile. For these reasons, we were initially quite skeptical about the possibility of turtles serving as hosts for VHSV IVb.

Our i.p. injection experiment demonstrated that VHSV IVb could still be found by qrt-RTPCR in turtles $21 \mathrm{~d}$ after challenge. However, given that our cell culture tests were negative, we could not rule out that the qrt-RTPCR was detecting non-replicating or nonviable virus that was present only as a residue of the injection challenge. The only evidence for replication in this first experiment is the intermittent appearance of VHSV in the water in which the turtles were living. While it is possible that the virus was merely leaking from the turtles, the pattern of reappearance suggested that new virus was being produced and shed by the turtles (a hypothesis that we tested more thoroughly using oral challenges in Expt 2).

The sporadic nature of our VHSV detection in the water by qrt-RTPCR is somewhat surprising. The VHSV IVb has been reported to persist for more than $10 \mathrm{~d}$ in fresh water at $15^{\circ} \mathrm{C}$ (Hawley \& Garver 2008), but our data implies something much briefer. This difference may be due to intermittent shedding combined with a shorter period of viability (attributable to the far higher amount of organic material present in our turtle containers). We can conclude only that virus injected i.p. in turtles does appear in the water for up to $18 \mathrm{~d}$ post injection.

We undertook the oral challenge experiment in an effort to more closely simulate a natural pathway of infection. Wild turtles would reasonably be expected to feed on moribund fish so in this experiment turtles were allowed to voluntarily feed on infected fish tissues. Our data shows that the virus moved from the lumen of the gut to the brain, kidney, and/or spleen (the samples were pooled by animal, not by organ). More importantly, on Day 3 the virus was not detected in any of 30 samples but the prevalence of infection on Day 10 post feeding was $38 \%$ (8 of 21 samples tested). This implies that the amount of virus present in turtles increased well after feeding of infected tissues ceased. It is also noteworthy that while the prevalence dropped from $38 \%$ on Day 10 to $13 \%$ (2 of 15 turtles) on Day 20, the titers in the 2 positive animals at $20 \mathrm{~d}$ were the highest that we found in the study and these were the only animals with VHSV detectable in cell culture. The best explanation of our findings is that the turtles became infected with VHSV IVb by an oral route and that the virus was successfully replicating in turtle tissues. 
There was significant turtle mortality during our oral exposure experiment but no evidence that the mortality was due to VHSV disease. Losses were sporadic, and when we tested moribund map turtles only 2 of 7 were VHSV IVb-positive. Based on the clinical signs, we attribute the turtle deaths to bacterial diseases triggered by the low temperatures used during our study. Turtles readily consumed the infected dead bluegill tissue at $14^{\circ} \mathrm{C}$, which suggests that they would eat VHSV-infected fish in the wild.

In our experiment using oral exposures, we did not measure virus titers in the water, nor did we co-habitate naïve fish with the infected turtles. Thus, we did not conclusively demonstrate that the movement of naturally infected wild turtles onto fish farms and hatcheries is a route for the introduction of VHSV IVb. However, our evidence of infection and replication in turtles exposed by a natural route does show that hatcheries in VHSV IVb-endemic areas should consider the movements of turtles in their biosecurity programs.

Our work also shows that it may be worthwhile to look at a broader group of poikilothermic animals to see if they propagate VHSV or other rhabdoviruses. The rhabdoviruses of fish, most notably VHSV and SVCV, have very broad host ranges (Batts \& Winton 2007, Goodwin \& Winton 2004), and it now seems possible that they may infect animals other than fish.

Acknowledgements. The authors thank J. R. Winton, G. Kurath, P. R. Bowser, J. W. Casey, and K. A. Garver for providing a VHSV isolate for our study, PCR assays for the detection of VHSV, and for their assistance in the design of our VHSV experiments. Funding for this work was provided by the USDA.

\section{LITERATURE CITED}

AVMA (American Veterinary Medical Association) (2007) AVMA guidelines on euthanasia (formerly Report of the AVMA Panel on Euthanasia). AVMA, Shaumburg, IL

Bain MB, Cornwell ER, Hope KM, Eckerlin GE, Casey RN and others (2010) Distribution of an invasive aquatic pathogen (viral hemorrhagic septicemia virus) in the Great Lakes and its relationship to shipping. PLoS ONE 5(4):e10156

Batts WN, Winton JR (2007) Viral hemorrhagic septicemia. In: AFS-FHS (American Fisheries Society-Fish Health Sec-

Editorial responsibility: Alex Hyatt,

Geelong, Victoria, Australia tion). FHS blue book: suggested procedures for the detection and identification of certain finfish and shellfish pathogens. AFS-FHS, Bethesda, MD

Doherty RL, Carley JG, Standfast HA, Dyce AL, Kay BH, Snowdon WA (1973) Isolation of arboviruses from mosquitoes, biting midges, sandflies and vertebrates collected in Queensland, 1969 and 1970. Trans R Soc Trop Med Hygiene 67(4):536-543

Elsayed E, Faisal M, Thomas M, Whelan G, Batts W, Winton J (2006) Isolation of viral haemorrhagic septicaemia virus from muskellunge, Esox masquinongy (Mitchill), in Lake St. Clair, Michigan, USA reveals a new sublineage of the North American genotype. J Fish Dis 29: 611-619

Goodwin AE (2002) First report of spring viremia of carp virus (SVCV) in North America. J Aquat Anim Health 14: 161-164

Goodwin AE, Winton JR (2004) Spring viremia of carp. In: AFS-FHS (American Fisheries Society-Fish Health Section). FHS blue book: suggested procedures for the detection and identification of certain finfish and shellfish pathogens. AFS-FHS, Bethesda, MD

> Hawley LM, Garver KA (2008) Stability of viral hemorrhagic septicemia virus (VHSV) in freshwater and seawater at various temperatures. Dis Aquat Org 82:171-178

Hogenhout SA, Redinbaugh MG, Ammar ED (2003) Plant and animal rhabdovirus host range: a bug's view. Trends Microbiol 11:264-271

> Hope KM, Casey RN, Groocock GH, Getchell RG, Bowser PR, Casey JW (2010) Comparison of quantitative RT-PCR with cell culture to detect viral hemorrhagic septicemia virus (VHSV) IVb infections in the Great Lakes. J Aquat Anim Health 22:50-61

> Lumsden JS, Morrison B, Yason C, Russell S and others (2007) Mortality event in freshwater drum Aplodinotus grunniens from Lake Ontario, Canada, associated with viral haemorrhagic septicemia virus, Type IV. Dis Aquat Org 76:99-111

> Miller O, Fuller FJ, Gebreyes WA, Lewbart GA and others (2007) Phylogenetic analysis of spring virema of carp virus reveals distinct subgroups with common origins for recent isolates in North America and the UK. Dis Aquat Org 76: 193-204

Monath TP, Cropp CB, Frazier CL, Murphy FA, Whitfield SG (1979) Viruses isolated from reptiles: identification of three new members of the family Rhabdoviridae. Arch Virol 60:1-12

> Peters F, Neukirch M (1986) Transmission of some fish pathogenic viruses by the heron, Ardea cinerea. J Fish Dis 9: 539-544

Van Regenmortel HV, Bishop DHL, Van Regenmortel MH, Fauquet CM (eds) (2005) Virus taxonomy: eighth report of the international committee on taxonomy of viruses. Elsevier Academic Press, Amsterdam

Submitted: June 23, 2010; Accepted: December 27, 2010 Proofs received from author(s): March 29, 2011 